\title{
AGRONOMIC PERFORMANCE OF SWEET CORN (Zea mays saccharata, Sturt) IN RUMBAIDISTRICT PEKANBARU
}

\author{
Surtinah $^{1)}$ \\ ${ }^{1)}$ Study Program of Agrotechnology, Faculty of Agriculture, Lancang Kuning University Pekanbaru, E-mail \\ :surtinah@unilak.ac.id Jl. YosSudarso, Km. 8 Rumbai, Pekanbaru. Telp. (0761) 52248
}

\begin{abstract}
The objective of the research was to get the varieties that give the best production in RumbaiPekanbaru. The treatment design was three varieties of sweet corn, namely Sweet Bor, Sweet Lady, and Bonanza varieties. The environmental design used was a complete randomized design withsix replications. The observation parameters were cob with bractea, cob without bractea, length of cob with bractea, unsweetened length of cob, diameter of cob, and sugar content. The results obtained that Sweet Lady varieties was the best varieties.
\end{abstract}

Keywords: Bonanza, Sweet boy, Sweet lady, Sugar levels, Varieties.

\section{INTRODUCTION}

The development of sweet corn in Pekanbaruis quite rapidly, this is due to the establishment of culinary outlets that made from sweet corn, especially in the Mall scattered throughout the corner of Pekanbaru city. The problem arises that the raw materials don't meet the demand of culinary traders, so the needs of sweet corn must be met from the neighboring province, namely West Sumatra.

This condition is very detrimental to processed food traders made from raw sweet corn, because the purchase price becomes higher, which resulted in smaller profits. Lidar and Surtinah (2012), reported that the low production of corn in Pekanbaru is caused by soil conditions dominated by PMK soil type, which contains little organic material and contains nutrients, so to empower the FMD soil needs additional organic material.

Another factor that causes low production of sweet corn in Pekanbaru is that the farmers do not selectively select the varieties in cultivating sweet corn. The farmer do not also use superior breeds
(Surtinah, Susi and Lestari, 2016). Distan (2012) informed that sweet corn production still needs to be improved, because Riau Province still lack 12191.67 ton or $96.98 \%$ of the reuqired.

The selection of appropriate varieties is one effort that can be done to increase the production of sweet corn in Pekanbaru. Based on the results of research conducted by Surtinah and Nurwati (2018), that there are three varieties that are recommended to be tested further planting, namely Sweet Boy, Sweet Lady and Bonanza. Based on research resultsof Rifianto and Gratitude (2013) explained that the growth and production of sweet corn will be different from each region, depending on the location of planting

The results of the research using varieties of Bonanza which was intercropped with peanuts, the cob weight was 319.45 gram, Sweet Boy varietiy with cob weight of 260.33 gram (Irvendi, 2016). In different studies (Surtinah, Susi and Lestari, 2016b) reported that the Bonanza varieties grown together with "kangkung sutra" reached 397.50 grams. Syafruddin, Nurhayati and Ratna (2012) reported that using the same 
varieties treated with NPK liquid provides high growth and production. Ebtan, Sugiharto, and, Widaryanto (2014) in a study conducted to obtain the weight of cobs Bonanza weighing of 421 grams per cob. The production of varieties of Bonanza reaches $8.23 \mathrm{Kg}$ perplot or equivalent to 12.85 ton per ha with cultivation techniques using different spacing (Wartono and Hamidah, 2012).

Seed sugar level that can be achieved by Bonanza varieties was $14.95 \%$ (Surtinah, 2013). In a study conducted by Surtinah and Nurwati (2018), the sugar content of sweet Lady varieties was $13.80 \%$, sweet boy $13.05 \%$, and Bonanza $13.73 \%$. In another study Surtinah et al. (2016a), reported that the sugar content of Bonanza varieties reached $14.95 \%$ in the intercropping system with "kangkung sutra". Seed sugar level of Sweet Boy varieties in the study conducted by Siswono (2004) reached $16 \%$. The results of research reported by Surtinah (2008) obtained Sweet Boy sugar level was $15.78 \%$ when harvested at the age of 70 days. The objective of the research was to obtain highyielding varieties in Rumbai Pekanbaru District.

\section{RESEARCH METHOD}

This research was conducted at Experimental Garden of Faculty of Agriculture, University of LancangKuning, with height of $20 \mathrm{~m}$ from sea level with Yellow Red Podsolik soil type, with pH 5.0. The research period started in February 2018 until May 2018.

The treatments used were varieties consisting of three varieties, namely; $\mathrm{v} 1=$ Sweet Boy, v2 = Sweet Lady, v3 = Bonanza, the environmental design used was a complete randomized design, with six repetitions. Data were analyzed by variance, and continued by Duncan 5\% range test.

The soil was processed two times before being used for the cultivation process, with the aim of turning the soil and looseningup the soil. In the second soil cultivation, mixing of manure from cow dung at a dose of 40 tons ha- 1 . The size of the experimental plot was $150 \times 100 \mathrm{~cm}$, and the distance between plots was $75 \mathrm{~cm}$. A week after the second ground cultivation was done sweet corn seedlingsplanted with $75 \times 20 \mathrm{~cm}$ hole planting spacing. Each plot contains ten plants and three plants used as sample plants.

The fertilizer used in this study was NPK 16:16:16, which was administered three times during the cultivation process, ie the first given at the time of planting, the second giving at three weeks after planting, and the third giving at the age of five weeks after planting, the dose of NPK fertilization was 3 grams per plant at planting time, and 5 gram per plant for the second and third fertilization.

The pesticide used was Decis 2.5 EC, given at fourth and eighth week after plant with concentration 2 ml liter- 1 water. Sweet corn crops watered twice a day as much as 1 liter of plant -1 . Harvesting done at age 65 days after planting.

Observations were made on the cob with bractea, the weight of cob without bractea, the length of the cob weighing, the length of cobs without bractea, the diameter of the cob, and the sugar content of sweet corn seed.

\section{RESULTS AND DISCUSSION}

The results obtained for all observation parameters are shown in Table1. Where the length of the cob with bractea, the weight of the cob without bractea, the weight of cob with bractea, the weight of the cob without bractea, the diameter of the cob was significantly different in the 5\% Duncan range test. While the content of sugar in sweet corn sugar was not significantly different between the three variets.

The length of cob with bracteaand the shortest length of cob without bractea obtained varieties Bonanza. The weight of 
cob with bracteaand weight of cob without the bractea obtained heaviest weight was Sweet Lady varieties, the largest diameter obtained varieties Sweet Boy and Sweet Lady, while the third sugar content of different varieties was not real.

Observations on the observed parameters showed that Sweet Lady varieties are varieties that show the best production in Kecamatan Rumbai. The length of cob without bractea obtained in a study conducted by Surtinah and Nurwati (2018) that Sweet Boy varieties was 33.17 $\mathrm{cm}$, Sweet Lady was $31.17 \mathrm{~cm}$, and Bonanza was $31.83 \mathrm{~cm}$. Sweet Lady varieties was longer than research in 2017, while Sweet Boy and Bonanza varieties of long cob without bractea was longer than the research in 2017.

The observation of cob weight with bractea and cob weight without bractea resulted the heavies was Sweet Lady varieties and was not significantly different with Sweet Boy varieties. When compared with the research conducted by Irvendi (2016), the weight of Bonanza varieties was 319.45 grams, and Sweet Boy was 260.33 grams, the weight of cob without bractea produced in this study for both varieties was lower. Surtinah and Nurwati (2018), reported that cob without bractea weight of Sweet Boy varieties was 275 grams, Sweet Lady was 292.83 grams, and Bonanza was 322.83 gram, there was a weight loss of cobs without bractea for the three varieties.

The best cob diameter was obtained by Sweey Boy and Sweet Lady varieties, while the diameter of Camanza varieties was the lowest. Rifianto and Gratitude (2013) reported that sweet maize given Urea $75 \%$ once added with $25 \%$ NPK yielded cobs diameter of $4.54 \mathrm{~cm}$. Compared with the third cob diameter the varieties tested in this study were greater. This reflects that the adaptability of the three sweet corn varieties to stimulate the cob diameter was good.

The third seed sugar level of the tested varieties showed an unequal difference, when compared with research conducted by Surtinah and Nurwati (2018), Sweet Boy, Sweet Lady and Bonanza sugar varieties were $13.05 \%, 13.80 \%$, and $13.73 \%$, then the third level of sugar varieties tested in 2018 was higher.

Table1. Average Generative Growth of Three Sweet Corn Varieties in Bukit Raya District.

\begin{tabular}{|c|c|c|c|c|c|c|}
\hline $\begin{array}{l}\text { Varieties } \\
\text { Tratment }\end{array}$ & $\begin{array}{l}\text { The length } \\
\text { of cob with } \\
\text { bractea } \\
\text { (cm) }\end{array}$ & $\begin{array}{c}\text { The } \\
\text { lenght of } \\
\text { cob } \\
\text { without } \\
\text { bractea } \\
(\mathrm{cm})\end{array}$ & $\begin{array}{l}\text { The cob } \\
\text { weight with } \\
\text { bractea }(\mathrm{g})\end{array}$ & $\begin{array}{l}\text { The cob } \\
\text { weight } \\
\text { without } \\
\text { bractea } \\
\text { (g) }\end{array}$ & $\begin{array}{c}\text { Cob } \\
\text { diameter } \\
(\mathrm{cm})\end{array}$ & $\begin{array}{c}\text { Seed } \\
\text { sugar } \\
\text { level }(\%)\end{array}$ \\
\hline Sweet Boy & $32.67 \mathrm{~b}$ & $20.84 \mathrm{a}$ & $397.28 \mathrm{~b}$ & $256.83 \mathrm{~b}$ & $5.18 \mathrm{~b}$ & $14.05 \mathrm{a}$ \\
\hline $\begin{array}{l}\text { Sweet } \\
\text { Lady }\end{array}$ & $32.67 \mathrm{~b}$ & $21.79 \mathrm{~b}$ & $419.50 \mathrm{~b}$ & $268.28 \mathrm{~b}$ & $5.18 \mathrm{~b}$ & $14.48 \mathrm{a}$ \\
\hline Bonanza & $30,61 \mathrm{a}$ & $20.82 \mathrm{a}$ & $349.22 \mathrm{a}$ & $224.50 \mathrm{a}$ & $4.81 \mathrm{a}$ & $14.17 \mathrm{a}$ \\
\hline
\end{tabular}

The number with lowercase letter which is similar is not significantly differenct according to yDMT p.0.05 


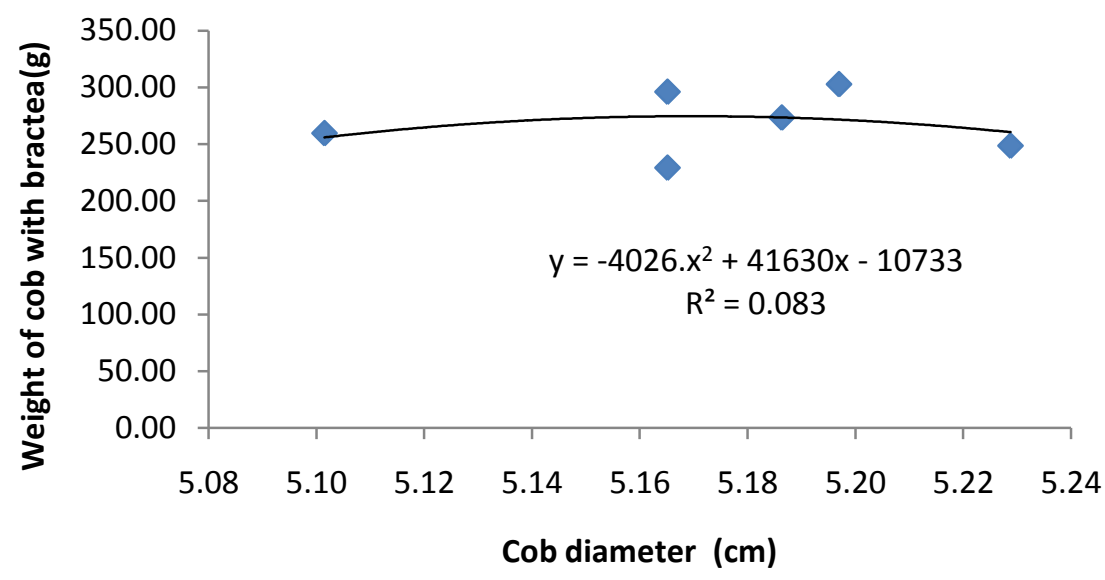

Figure1. Sweet Boy The relationship between cob diameter with varieties cob weight with bractea

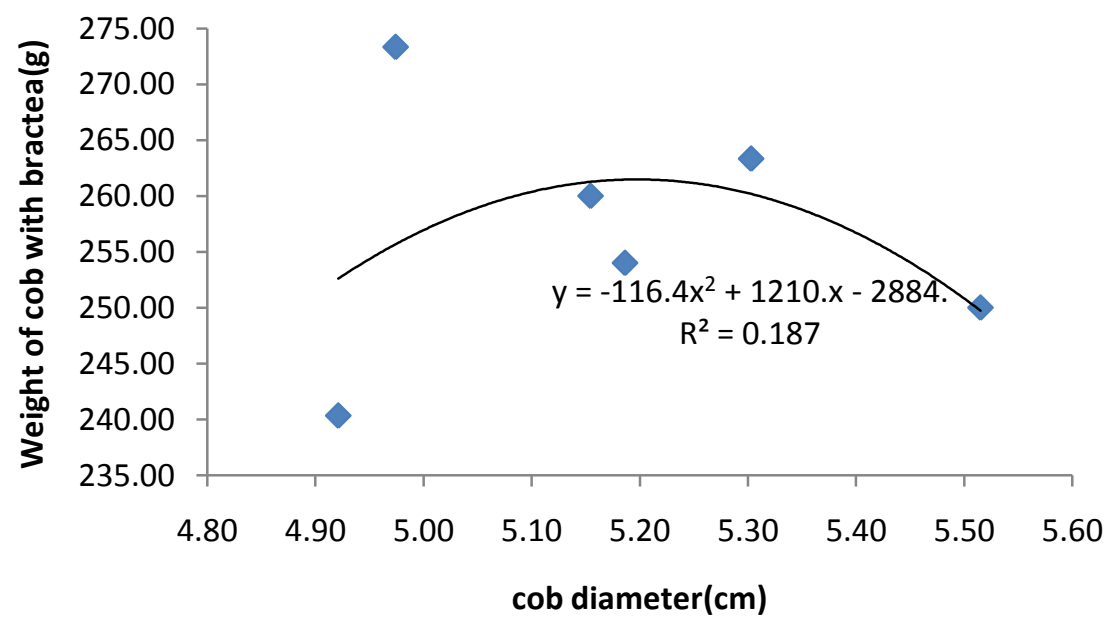

Figure2. Relationship between cob diameter with Sweet Lady varieties cob weight with bractea.

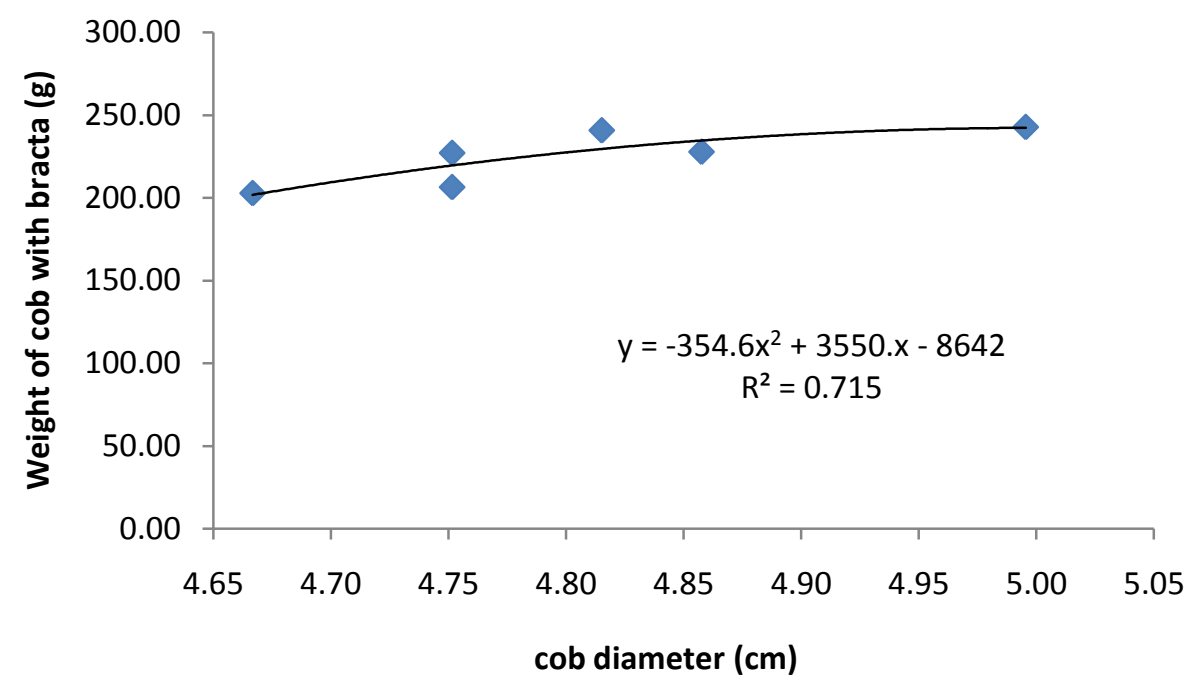

Figure3. Relationship between cob diameter with Bonanza cob weight with bractea. 
The weight of cobs with bractea of Sweet Boy and Sweet Lady varieties was not influenced by the diameter of cob, this was proved by the value of correlation of varieties there were $8.32 \%$ and $18.75 \%$. whereas the cob diameter for Bonanza varieties influenced the weight of the swollen cob with the value of $\mathrm{R} 2=71.50 \%$. It was alleged that this phenomenon causes the weight of Sweet Boy and Sweet Lady cob varieties to be significantly different, while the Bonanza varieties was influenced by the diameter of the cob. The diameter of sweet Boy and Sweet Lady varietiescob had reached the maximum in this study and had given maximum contribution in increasing the weight of cob weighing both varieties. The magnitude of the tuna diameter illustrated the amount of dry material stock that accumulates resulting in increased cob weight. In the Bonanza varieties the accumulation of dry matter as a reserve that will be used to increase the weight of tuna is still not maximized. In this study the harvest was done at age 65 days after planting, while the description suggested harvest at age 82-84 days after planting. A study conducted by Surtinah (2017), reported that varieties of Bonanza harvested at 65 days after planting yielded a $5.18 \mathrm{~cm}$ cob diameter, in another study (Surtinah, 2008) reported that sweet corn harvested at 65 days after transplanting produced seeds softer fibers compared to 70 , and 75 days after planting.

\section{CONCLUSION}

The conclusion of this study is Sweet Lady varieties is a varieties that is recommended to be cultivated in the District of Rumbai, this is because of all observation parameters of cob with bractea and sugar content of seeds, Sweet Lady varieties was the best varieties compared to the two other varieties.

\section{ACKNOWLEDGEMENT}

Thank you to the Rector of Lancang Kuning University who has funded this research, and thankyou to all those who have assisted in this research.

\section{REFERENCES}

Distan. (2012). Petunjuk Teknis Peningkatan Mutu Intensifikasi (PMI) dan Pengembangan Tanaman Jagung. Dinas Tanaman Pangan dan Hortikultura Provinsi Riau.

Irvendi. (2016). Pertumbuhan dan Hasil Varietas Jagung Manis (Zea mays saccharata Sturt) dalam Tumpangsari Kacang Tanah (Arachis hipogea L.). J. Agrotropika, 3(3), 1-10.

Lidar, S., dan Surtinah. (2012). Respon Tanaman Jagung Manis Akibat Pemberian Tiens Golden Harvest. J.Ilmiah Pertanian, 8(2), 1-6.

Rifianto, A., dan Syukur, M. (2013). Daya Gabung Hasil dan Komponen Hasil Tujuh Galur Jagung Manis di Dua Lokasi Combining Ability of Yield and Yield Components of Seven Sweet Corn Lines Across Two Locati ons. Jurnal Agronomi Indonesia, 41(3), 235-241.

Ringga Ebtan, S., Sugiharto, A. N., dan Widaryanto, E. (2014). Ketahanan Beberapa Varietas Jagung Manis (Zea mays Saccharata Sturt) terhadap Populasi Gulma Teki (Cyperus rotundus). J. Produksi Tanaman, 1(6), 471-477.

Siswono. (2004). Jagung manis rendah lemak dan kolesterol. Retrieved from www. gizi net

Surtinah. (2008). Umur Panen yang tepat menentukan kandungan gula biji jagung manis (Zea mays saccharata, Sturt). J.Ilmiah Pertanian, 4(2), 1-6. 
Surtinah. (2013). Menguji 3 Varietas jagung manis di Rumbai Pekanbaru. J. Ilmiah Pertanian, 1(1), $1-10$.

Surtinah. (2017). Potensi hasil jagung manis ( Zea mays saccharata, sturt) dengan pemberian paket teknologi pupuk dan zat pengatur tumbuh, 2(1), 37-44.

Surtinah, dan Nurwati, N. (2018). Selecting the Right Varieties in Riau Main Island: Sweet Corn Context. In IOP Conference Series: Earth and Environmental Science (p. 12062). IOP Publishing. https://doi.org/doi :10.1088/1755-1315/156/1/012062

Surtinah, Susi, N., dan Lestari, S. U. (2015). Komparasi Tampilan dan Hasil Lima Varietas Jagung Manis ( Zea mays saccharata, Sturt) di Kota Pekanbaru. J. Ilmiah Pertanian, 13(1), 32-37.

Surtinah, Susi, N., dan Lestari, S. U. (2016). Optimasi Lahan Dengan Sistem Tumpang Sari Jagung Manis (Zea Mays Saccharata, Sturt) Dan Kangkung Sutra (Ipomea Reptans) Di Pekanbaru Oleh. J. Ilmiah Pertanian, 12(2), 62-72.

Syafruddin, Nurhayati, dan R, W. (2012). Pengaruh jenis pupuk terhadap pertumbuhan dan hasil beberapa varietas jagung manis. J. Floratek, 7(1).

Wartono, dan Hamidah. (2012). Pengaruh Varietas dan Jarak Tanam terhadap Pertumbuhan Produksi Jagung Manis (Zea mays saccharata Sturt). J. Agro Silampari, 1(51-61). 